\title{
超音波ドップラー流速プロファイラー（ADCP）を用いた 感潮水域における流動観測例
}

\author{
藤井 智康・吉村 亮・三村 敬・奥田 節夫・横山 康二
}

\section{Test Application of Acoustic Doppler Current Profiler to Current Measurements in Tidal Water Areas}

\author{
Tomoyasu FujII, Makoto Yoshimura, Takashi Mimura, \\ Setsuo OKUDA and Koji YoKoYama
}

\begin{abstract}
An Acoustic Doppler Current Profiler (ADCP) recently developed to measure current distribution in the ocean based on the Doppler shift principle has been tested for limnological studies. We had a chance to test the ADCP in brackish lakes, Nakaumi and Shinjiko, and a tidal river Ohashigawa on 25 27 Aug. 1992, and succeeded in continuous measurements of current distribution in those water areas.

From our test observation, we found that the employment of ADCP in tidal water areas is very effective for rapidly recording current patterris in stratified double layers.

However, ADCP is not so applicable to measurements in shallow water areas or weak current fields, because we cannot measure currents in the layers near the water surface and bottom due to limitations in the acoustic method, and we found that a low current speed relative to navigational speed may result in a large error.
\end{abstract}

Key words : $\mathrm{ADCP}$, current measurement, brackish lake and tidal river, current visualization

\section{1.はじめに}

湖沼・河川において水の流れの場の空間的分布 や時系列変化を紐かく追求するためには，従来の 流速計を用いての定点観測や航走観測では，多数 の流速計を用いた同時多点連続観測や観測船によ る移動観測の繰り返しが必要であった。

しかし，現実的には人員的・経費的な制約ある いは航路上の船のひんぱんな往来のために，近年 では長時間にわたる定点観測あるいは航走観測の 実施はきわめて困難な場合が多くなってきた。

そこで，最近開発された超音波のドップラーシ フトを利用した流速計である超音波ドップラー流 速プロファイラー (Acoustic Doppler Current Profiler；略称 ADCP) の利用が注目されてきた。

この方法によると，瞬時に鉛直方向の多層にわ たる流速の 3 成分を測定して, 水域の三次元的流
れの場を調べることが可能である。このため近年 海洋観測において, 大洋や海峡などの強流域の海 流および潮流の分布また海水の交流状態などを対 象とした可視化あるいは迅速な数値データの処理 を可能にし, ADCP が有効な手段であることが確 かめられている(高杉活か，1987，1990；藤原ほ か, 1989)。

しかしながらこの手法を沿岸や内陸の感潮水域 で適用することは未だ行われていなかった。この ため，われわれは今回中海，宍道湖および大橋川 で ADCPを利用しての流れの場の観測を実施し， その適用の効果あるいはその問題点を調べた。

なお, ADCP の測流原理についてはすでに海洋 学分野の文献(例えば高杉ほか, 1987 ; 藤原ほか, 1989）に紹介されているので記述は省略し，われ われの試みた感潮水域での観測の方法と成果につ いてのみ報告する。 


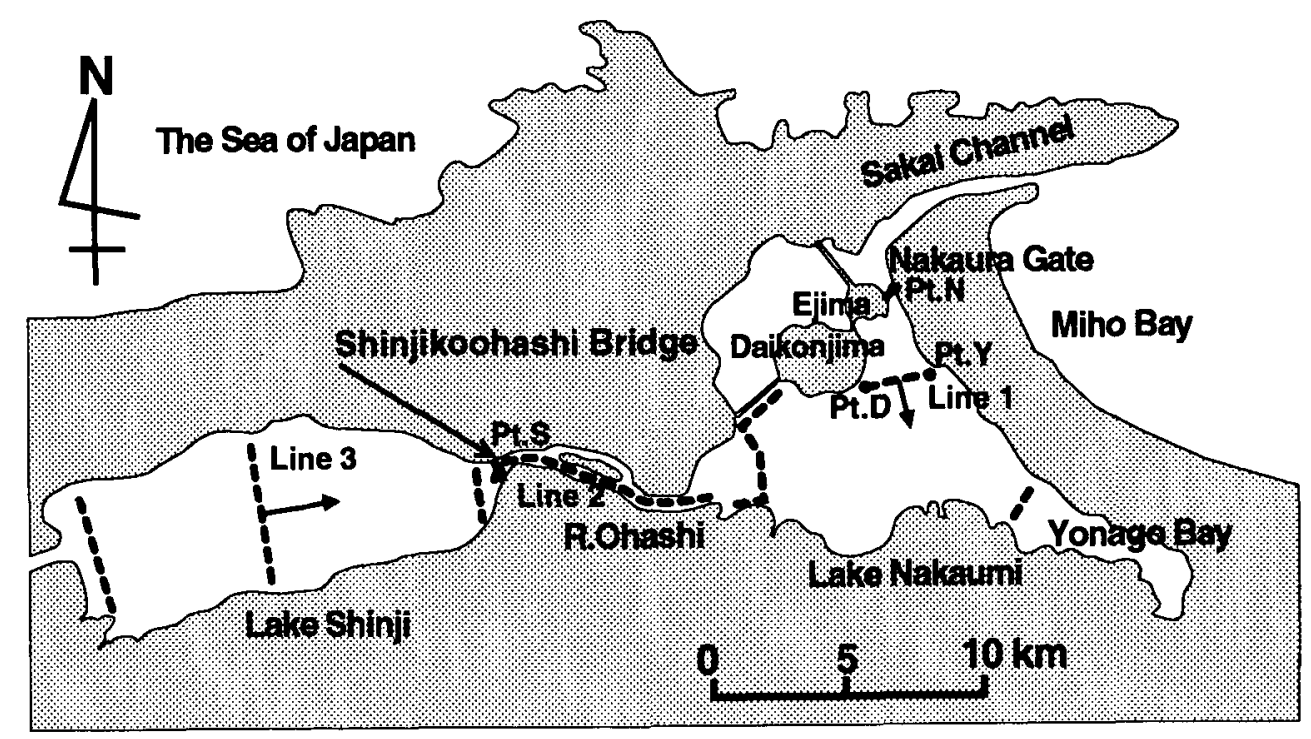

Fig. 1. Map of Lake Shinji, Lake Nakaumi and Sakai channel. Dotted lines of map show ship tracks for current measurement with $\mathrm{ADCP}$. Measurement results along lines $1 \sim 3$ are shown in Figures $2 \sim 5$.

\section{2. 観測地点および観測方法}

Figure 1 に示すように，中海は長さ約 $7.5 \mathrm{~km}$ の境水道を通じて日本海とつながり，また中海・ 宾道湖は長さ約 $7.7 \mathrm{~km}$, 平均水深 $4.5 \mathrm{~m}$ \%大橋 川によって結ばれており，これらの水域は連系汽 水域を構成している。

この水域における流れの観測は，島根県および 岡山理科大学の調查グループによって施行されて いるがまとまった資料としては未だ報告されてい ない。これまでの経験によると，長い測線に沿っ て流速の鉛直分布を従来の流速計を用いて測定す るには長い時間を要し，時間的に変動の速い感潮 水域での変動特性を捉えることはきわめて難し い。

そのうち大橋川においては潮汐にともなって往 復流が発生し, 中海, 宍道湖の塩分分布の差のた めに雨水域の水の接触混合によって複雑な流速分 布を呈している(吉村, 1993)。

そこで特定の測線に沿った航走によって流れの パターンを短時間に測定できる ADCP の利用を 試みた。

観測は, 1992 年 8 月 25 日に中海 (5 測線)，26 日に大橋川 (1 測線 3 回), 27 日に宍道湖 (3 測線) に扔いて，米国 RD Instruments 社製の ADCP を 用いて行われた (Fig. 1)。測定精度は土2 $\mathrm{cm} \cdot \mathrm{sec}^{-1}$ 程度である。

この観測測線の選択は島根県水産試験場の今後
の水域調査計画を配慮して定められた。

ADCP の取付けについては，穏やかな水域で小 回りのきくよう，今回は船の䑪側に取りつける方 法を採用した。

$\mathrm{ADCP}$ トランスデューサー発信音波は 1200 $\mathrm{kHz}$ で, 発信のインターバルを $4.5 \mathrm{sec}$ とし, 測定 は水深 $1.16 \mathrm{~m}$ 以深を $0.5 \mathrm{~m}$ 間隔で 1 地点 44 層 の記録を行った。つまり, 水深 $23 \mathrm{~m}$ まで測定可能 である。これは, ADCP デー夕管理・処理プログ ラム“Transect”により各水域の観測航路の水深 変化を考慮し，試験的に設定を行った。

水深の上限で $1.16 \mathrm{~m}$ とした理由は, ADCP の 反射時間の短い表層部分 (水深約 $1 \mathrm{~m}$ ) で測定不可 能なためである。また一般に水底からの乱反射に よるビーム強度増大によって音響ビームの鉛直方 向からの傾きが $30^{\circ}$ のをき $\mathrm{H} \cos 30^{\circ}=0.8 \mathrm{H}$ （H： 全水深) 以深の底層部分で測定できない。観測に 扔いて航走速度は平均 4 ノット(約 $2 \mathrm{~m} \cdot \mathrm{sec}^{-1}$ ), 従って $4.5 \mathrm{sec}$ 間隔のパルス発信によって約 $9 \mathrm{~m}$ 間隔でデータが得られる。また生データではその 数が非常に多く図化するのに非常に手数がかかる ので, データは航走距離に応じて 10〜50 個のデー 夕の平均を行い図化した。

原理的に測定できない表層付近のデータは，他 の観測船が ADCP 観测船に併行して航走し, ア レック電子製電磁流向流速計（測定精度 \pm 0.5 $\left.\mathrm{cm} \cdot \mathrm{sec}^{-1}\right)$ を用いて測定した。また底層のデータ は，水底で流速ゼロとなるように線形補間を行っ 
た。

電気伝導度測定には塩分・水温・水深の同時測 定を行うアレック電子製メモリーSTD (Salinity, Temperature, Depth meter; 測定精度: 水温土 $0.02^{\circ} \mathrm{C}$, 塩分 $\pm 0.05 \%$, 深度 $\pm 0.11 \%$ ）用い, アレック電子データ処理プログラムにより電気伝 導度 (測定精度 : $\pm 0.1 \mathrm{mS} \cdot \mathrm{cm}^{-1}$ ) に換算される。 また, 航走中の現在位置は, 全地球測位システム

(Global Positioning System : 略称 GPS) を用 いて決定し,この測定精度は,この水域では $15 \mathrm{~m}$ 程度である。
3. 観 測 結 果

\section{3-1. 大橋川}

宍道湖と中海とをつなぐ大橋川は，両湖の水位 変動や塩分分布の影響を受けて複雑な流動を示 す。特に宍道湖からは流机出る淡水と中海から遡 上する塩水の混合によって, 強混合状態, 緩混合 状態, 弱混合状態あるいはそれらが全て出現する 複合混合状態とも言うべき状態がしばしば観测さ れる(島根県衛生公害研究所, 1991 ; 吉村, 1993)。

また, 大橋川を遡上する塩水の挙動は, 宾道湖

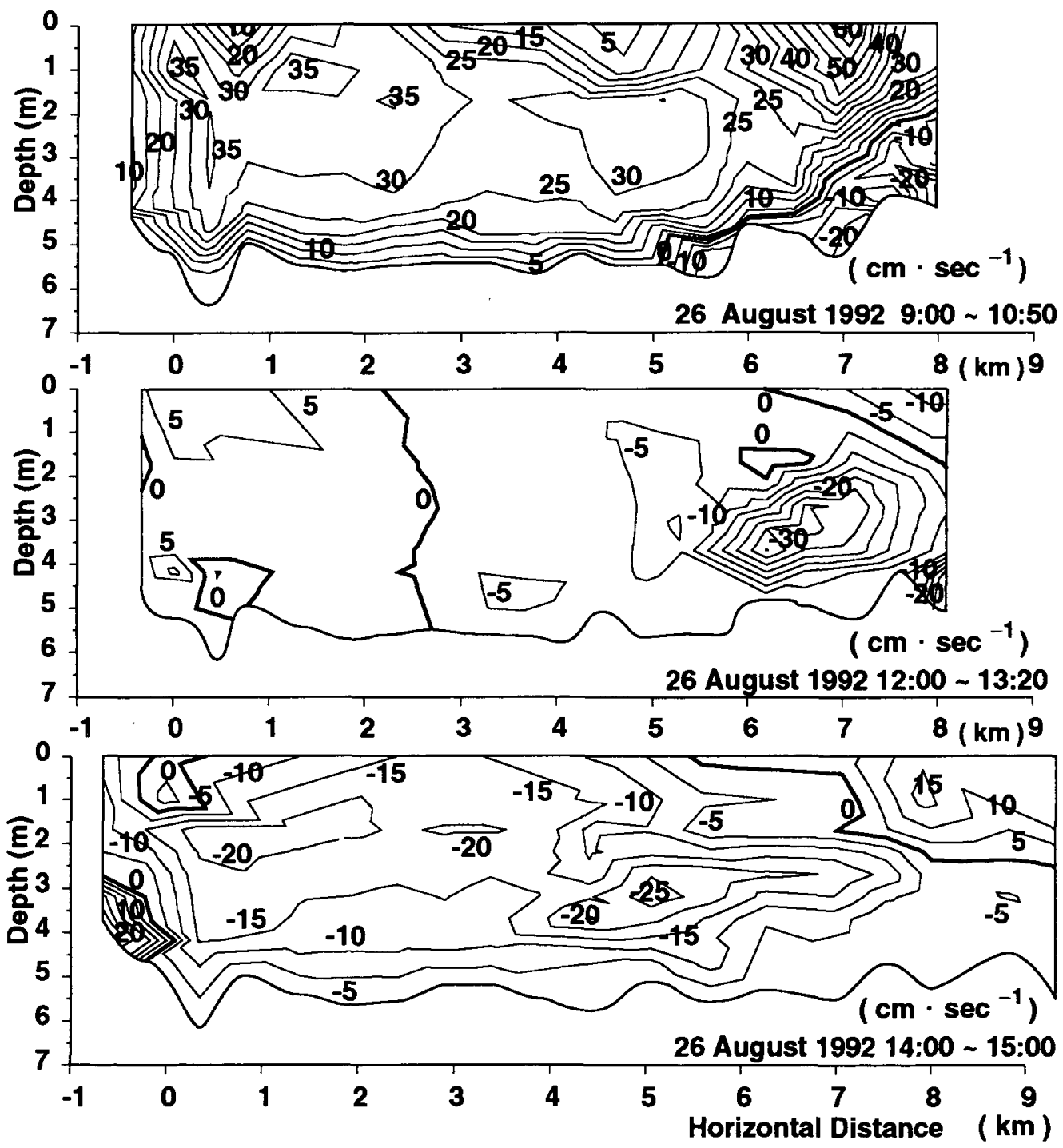

Fig. 2. Velocity distribution map with ADCP analysis along line 2 at R. Ohashi (shown in Fig. 1) on 26 August 1992. Positive values of velocity correspond to the direction from L. Shinji to L. Nakaumi in line 2 (shown in Fig. 1). 
に供給する塩分フラックスを決定する重要な要因 である。その挙動を知るためには大橋川の詳紐な 電気伝導度分布状況・流速分布状況を迅速に観測 しなければならない

われわれは，1992年 8 月 26 日に 3 回にわたり 大橋川を䋊断して ADCPによる流速観測を行な い, 同時に他の一隻の観測船が ADCP 観測船に併 行して航走し,STD を用いて電気伝導度分布状態 を観測した。ADCP 観測結果に上層部分では電磁 流向流速計測定デー夕を加え, 水底の流速をゼロ として線形補間を行った結果を Figure 2 に示し， 電気伝導度分布図を Figure 3 亿示す。宍道潮大橋 下 (Fig. 1の Pt.S) の水面を原点とし横軸に宍道 湖加ら中海に向かう河道に沿った航走距離 $(\mathrm{km})$,
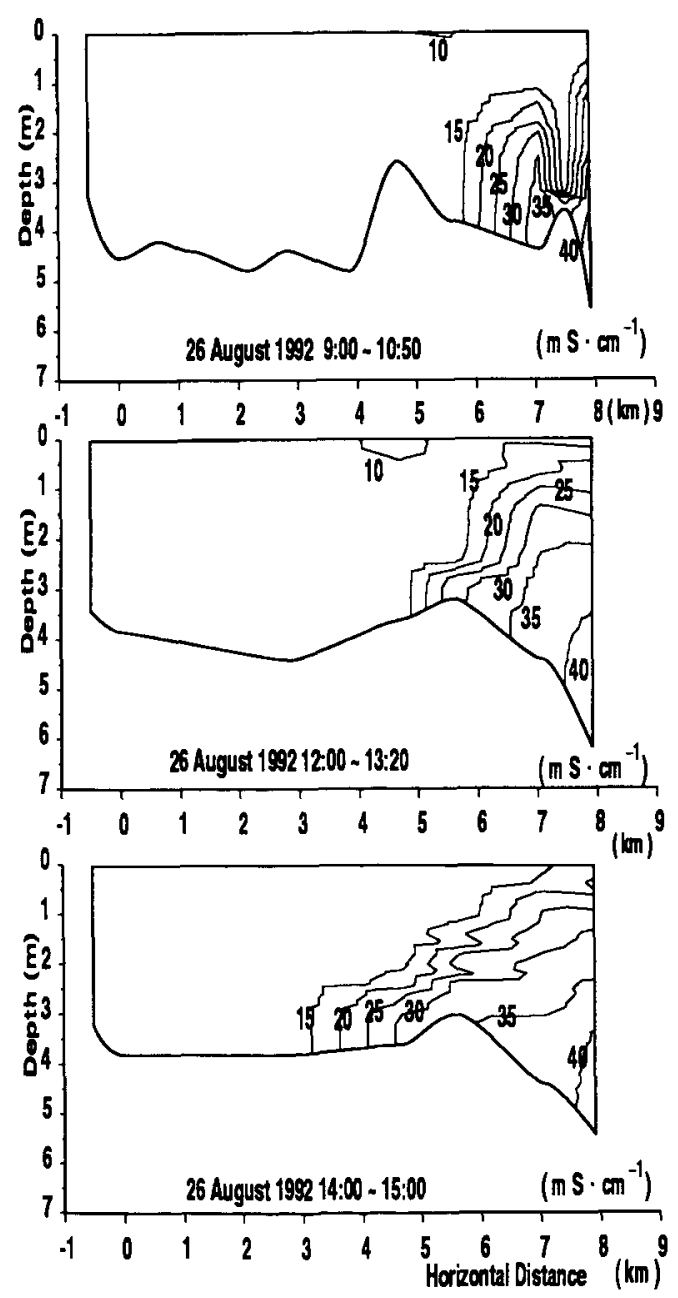

Fig. 3. Electric conductivity distribution measured with STD along line 2 of R. Ohashi (shown in Fig. 1) on 26 August 1992.
縦軸に水深 $(\mathrm{m})$ をとった。

流速分布図では河道に沿って突道湖から中海に 向かう流れを正値 (プラス) に, 中海から宍道湖 に向かう流机を負值（マイナス）に示した。

Figure 2 にると，時間経過とともに徐々に流 向が逆転してゆく様子がわかる。1 回目の観測で は中海側の下層部分にのみ負の流速值を示す領域 が存在し, 2 回, 3 回目の観測でこの領域が中海か ら突道湖に範囲が広がってゆき, 水塊が遡上して いく過程が観測された。

同時に観測した電気伝導度の分布図 (Fig. 3) に よると, 1 回目の観測では中海側の下層に高い值 $30 \mathrm{mS} \cdot \mathrm{cm}^{-1}$ (塩分濃度に換算するとほほ $17 \%$ ) を示しているが, 2 回目, 3 回目になるにしたがい 徐々に高い電気伝導度を示す部分が底に沿って楔 状に宾道湖に向かって遡上していることが分か る。

電気伝導度分布と流速分布図を対此すると, 1 回目の観測では高塩分水が存在する部分において 流速の負值が対応し, 淡塩水混合部分 $(7 \sim 8 \mathrm{~km}$ 付 近）においては密度躍層の存在が確認できる。し かし,2 回目, 3 回目の観測では流速の“マイナス” 域と高い電気伝導度を示す部分は一致していな い。

このことは，大橋川を遡上する塩水は，まず中 海側入口の下層においては鉛直混合の程度が弱い 塩水楔を形成するが, 塩水が遡上するにしたがい, 次第に大橋川全体の流れを弱め，低い電気伝導度 を示す低塭分水を宾道湖に押し戻しながら徐々に 塩水が遡上することを示している。

大橋川における塩水挙動を知るために行ったわ れわれの従来の観測では, 電気伝導度分布を重視 して, 鉛直混合の程度の異なる状態が大橋川内に 同時に存在し得ることを指摘しているが，流速分 布が解明できた今回の ADCP 利用の観測によっ て, 新たな視点から大橋川の淡塩水の往復流を捉 える可能性が示された。

\section{3-2 中海・穴道湖}

中海での観測の一例として, 大根島龟崎沖 (Fig. 1 の Line 1 の西端 Pt. D) 加米子空港沖 (Fig. 1 のLine 1 の東端 Pt. Y) に向かう測線沿いの上げ 潮時の観測 (Fig. 4) では, 測線の西端付近で全体 的に流速ゼロの領域が存在し, 測線の東端に近づ くにしたがって流れが強くなり，また水深が深く なる東端で流れも特に強くなっていることが認め られた。

これは，測線の西端付近は島や岩礁の影響で水 の運動が妨げられているのに対して, 測線の東端 


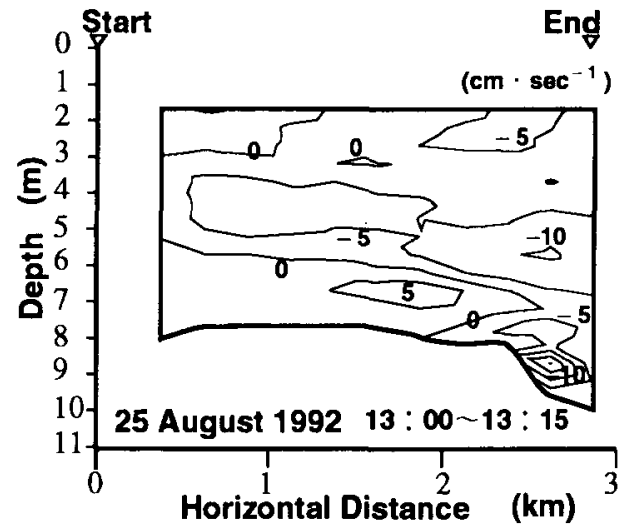

Fig. 4. Velocity distribution map with ADCP analysis along line 1 in Lake Nakaumi (shown in Fig. 1) on 25 August 1992. Positive values of velocity correspond to the direction of arrow in line 1 (shown in Fig. 1).

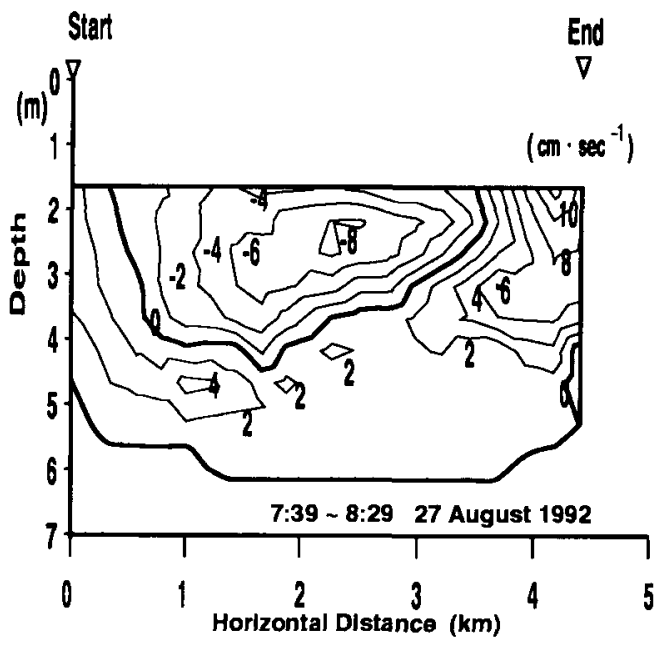

Fig. 5. Velocity distribution map with ADCP analysis along line 3 in Lake Shinji (Shown in Fig. 1) on 27 August 1992. Positive values of velocity correspond to the direction of arrow in line 3 (shown in Fig. 1).

は水深が深く湖岸地形も平滑で流水に対する抵抗 が少ないためと考えられる。

宍道湖での観測の一例として, 宾道湖湖心を南 北に横断する測線（Fig. 10 Line 3）沿いの観測 で, 中央部と湖岸付近で流れが逆向きになってい ることが認められた（Fig. 5)。

これは恐らく斐伊川の河川流入による流れ, 風
の吹走作用および潮汐干満による流れとが結びつ いて湖内にいくつかの環流が形成されていること を示唆するが，その確認は今後の調査をまたねば ならない。

\section{4. まとめ}

以上のような観測例から分かるように, $\mathrm{ADCP}$ を用いると従来の流速計による測定と異なり, 比 較的短時間にかなり広い水域の流速の空間的分布 を測り得ることができる。

今回の観測より ADCPを利用した湖沼・河川に おける流速分布測定の利点と欠点は次のようにま とめられる。

（1）流速の空間的変動が激しい場所やかなり広 い水域では,空間的に連続した航走観測によって， 場所的特異性がその場で明らかとなる利点があ る。

（2）湖沼・河川において, 現在可能な ADCP の 装置では底層（水深 $80 \%$ 以深）と水面近く（水深 約 $1 \mathrm{~m})$ の流速が測定不能であり, 浅水域での測定 範囲がかなり限定される。(ただし，ビーム角度の 減少によってこの範囲を広げることは可能)

また，测定精度が土 $2 \mathrm{~cm} \cdot \mathrm{sec}^{-1}$ 程度のために弱 流に対しては大きな相対誤差を生じる。

\section{摘 要}

最近開発された超音波ドップラー流速プロファ イラー $(\mathrm{ADCP})$ は，海洋観測においては実用化さ れているが，陸水学的研究にはいまだ利用されて いない。われわれは，1992 年8月 25 日〜27日に わたって，汽水湖である中海，宍道湖，および感 潮河川である大橋川において，ADCPを流速测定 のために試行的に利用する機会を得た。今回の ADCP を用いた試験的観測結果によって, 迅速か つ連続的な測定が可能であり，とくに成層構造を もった二重層の流れを記録することが出来るとい う点で,このような水域での観測にはきわめて効 果的であることが認められた。また，この方法は， 簡単なデータ処理によって，流れのパ夕ーンを可 視化するのにも非常に便利である。ただしここの 方法は表層と水底近くでの測定が不可能であり， また船速に対して弱い流れの場では測定䛊差が大 きくなるので浅い水域や流れの弱い場では有効に 利用できない。

\section{文献}

Fujwara, T., Y. Takasugl and T. Higo (1989): Visualization of flow in coastal waters with Acous- 
tic Doppler Current Profiler, Jour. Japan Soc. Mar. Surv. Tech. 1, 1: 57-65.

Takasugi, Y., T. Higo and H. Noguchi (1987): Characteristics of velocity distributions in a strait: Current measurement by Doppler Current Profiler, La Mer, $25:$ 167-174.

島根県衛生公害研究所(1991)：大橋川における栄養塩 フラックス調查報告書

吉村 亮(1993)：感潮河川に㧍ける塩水の楜上につい

て. 岡山理科大学大学院理学研究科修士論文

(著者：藤井智康・吉村 亮・三村 敬, 岡山理科
大学大学院理学研究科, 奥田節夫, 岡山理科大学理学 部, $\overline{7} 700$ 岡山市理大町 1-1 ; 横山康二, 京都大学防災 研究所, $=611$ 京都府宇治市五ヶ庄; Tomoyasu FujII, Makoto Yoshimura, Takashi Mimura and Setsuo OKUDA, Faculty of Science, Okayama University of Science, 1-1 Ridaicho, Okayama, 700; Koji Yoкоуама, Disaster Prevention Research Institute, Kyoto University, Gokasho Uji, Kyoto, 611)

1993 年 5 月 14 日 受付 1993 年 10 月 1 日 受理 